\title{
ROS (Reactive Oxygen Species)-Generating Systems in Mitochondria, Microsomes and Peroxisomes
}

\section{Hideharu Shintani*}

Chuo University, School of Science, 1-13-27, Kasuga Bunkyo 112-0003 Tokyo, Japan

Keywords: Reactive Oxygen Species; Bovine Heart Submitcondrial particles; Microsomes; Liver; Malondialdehyde

\section{Preparation of each fraction}

\section{Bovine heart submitchondrial particles (SMP)}

Protocol: Keep the sample temperature below $4^{\circ} \mathrm{C}$ whenever possible.

1. Put fresh bovine heart obtained from a slaughter house in a vinyl bag and keep on ice during transfer.

2. Remove fat and endothelium, cut into $2-3 \mathrm{~cm}$ cubes and keep on ice in a vinyl bag until mincing.

3. Mince with an electric food cutter for ca 1 min and keep on ice in a vinyl bag. It is possible to stop experiments by freezing the mince in a vinyl bag at this step. For quick freezing and thawing, the mince should be spread thinly in the bag. Usually, $1-2 \mathrm{~kg}$ of the mince is used for the preparation of SMP.

4. Suspend in ice-cold $0.25 \mathrm{M}$ sucrose- $0.185 \% \mathrm{~K}_{2} \mathrm{HPO}_{4}(3 \mathrm{~L} / \mathrm{kg}$ mince).

5. Adjust $\mathrm{pH}$ to ca 7.5 quickly by adding $6 \mathrm{M} \mathrm{KOH}(8-10 \mathrm{~mL} /$ $\mathrm{kg})$.

6. Homogenize with a food mixer at maximum power for $2 \mathrm{~min}$ The homogenates should be kept on ice until centrifugation.

7. Centrifuge at $2000 \mathrm{~g}$ for $10 \mathrm{~min}$ (Hitachi RPR 12-2 rotor, 4600 rpm).

8. Decant the supernatant and filter through four layers of gauze.

9. Centrifuge the supernatant at $11000 \mathrm{~g}$ for $40 \mathrm{~min}$ (Hitachi RPR 12-2 rotor, $10600 \mathrm{rpm}$ ).

10. Suspend the pellet in a small volume of sucrose $(0.25 \mathrm{M}$, 40-80 $\mathrm{mL}$ ) and homogenize with a Potter-Elvehjem type homogenizer (3-5 strokes). The homogenizer should be kept in the ice-water bath during homogenization.

11. Dilute the homogenate with sucrose $(0.25 \mathrm{M}, 400-800 \mathrm{~mL})$.

12. Centrifuge at $11000 \mathrm{~g}$ for $40 \mathrm{~min}$.

13. Repeat procedures 10-12 twice more.

14. Suspend in sucrose $(0.25 \mathrm{M}, 10-20 \mathrm{~mL}$ ) containing EDTA (pH $7.5,2 \mathrm{mM}, 30 \mathrm{mg} / \mathrm{mL})$.

15. Freeze at $-20^{\circ} \mathrm{C}$ for at least 3 days.

16. Thaw quickly in flowing water.

17. Sonicate $10 \mathrm{~mL}$ of the mitochondrial sample six times for $45 \mathrm{~s}$ at $1 \mathrm{~min}$ intervals (Branson sonifier, cell disrupter 200, output 3.5-5.0 with a flat tip). The sample should be kept in the icewater bath during and between sonications.
18. Centrifuge at $12000 \mathrm{~g}$ for $15 \mathrm{~min}$ (Hitachi RPR20 rotor, 13000 rpm).

19. Centrifuge the supernatant at $77000 \mathrm{~g}$ for $1 \mathrm{~h}$ (Hitachi RP30 rotor, $30000 \mathrm{rpm}$ ).

20. Suspend the pellet in a small volume of sucrose $(0.25 \mathrm{M})$ containing EDTA $(2 \mathrm{mM})$ and homogenize with a PotterElvehjem type homogenizer (3-5 strokes).

21. Repeat procedures 18-20 twice more.

22. Finally suspend and homogenize in several $\mathrm{mL}$ sucrose $(0.25$ M) containing Hepes ( $5 \mathrm{mM}), \mathrm{NaOH}(5 \mathrm{mM})$, and EDTA $(0.1$ $\mathrm{mM})(\mathrm{pH} 7.5)$.

23. Store at $-20^{\circ} \mathrm{C}$.

\section{Comments}

1-2 g mitochondria are obtained from $1 \mathrm{~kg}$ mince. The recovery of sub-mitochondrial particles from the mitochondrial fraction is 20 $30 \%$.

\section{Rat liver microsomes}

\section{Protocol}

1. Perfuse rat liver with cold saline.

2. Cut into pieces with scissors and suspend in $8 \mathrm{~m} \mathrm{~L} / \mathrm{g}$ wet weight of sucrose $(0.25 \mathrm{M})$, Hepes ( $5 \mathrm{mM}), \mathrm{NaOH}(5 \mathrm{mM})$, and EDTA $(0.1 \mathrm{mM})$ at $\mathrm{pH} 7.4$.

3. Homogenize with a Potter-Elvehjem type homogenizer (3-5 strokes).

4. Centrifuge at $7000 \mathrm{~g}$ for $10 \mathrm{~min}$ (Hitachi RPR20 rotor, 10000 rpm).

5. Centrifuge the supernatant at $77000 \mathrm{~g}$ for $1 \mathrm{~h}$ (Hitachi RP30, $30000 \mathrm{rpm}$ ).

6. Suspend the pellet in sucrose $(0.25 \mathrm{M})$, Hepes $(5 \mathrm{mM}), \mathrm{NaOH}$ (5 $\mathrm{mM})$, and $\operatorname{EDTA}(0.1 \mathrm{mM})$ at $\mathrm{pH} 7.4$.

7. Homogenize with a Potter-Elvehjem type homogenizer (3-5 strokes).

Corresponding author: Hideharu Shintani, Chuo University, School of Science 1-13-27, Kasuga Bunkyo 112-0003 Tokyo, Japan, Tel: +81425922336; E-mail: shintani@mail.hinocatv.ne.jp

Received May 14, 2013; Accepted June 24, 2013; Published June 28, 2013

Citation: Shintani H (2013) ROS (Reactive Oxygen Species)-Generating Systems in Mitochondria, Microsomes and Peroxisomes. Pharm Anal Acta 4: 242 doi:10.4172/2153-2435.1000242

Copyright: (c) 2013 Shintani H. This is an open-access article distributed unde the terms of the Creative Commons Attribution License, which permits unrestricted use, distribution, and reproduction in any medium, provided the original author and source are credited. 
8. Centrifuge at 770009 for $1 \mathrm{~h}$.

9. Repeat procedures 6-8 twice more.

10. Suspend and homogenize in a small volume of sucrose $(0.25$ $\mathrm{M})$, Hepes (5 mM), $\mathrm{NaOH}(5 \mathrm{mM})$, and EDTA $(0.1 \mathrm{mM})$ at $\mathrm{pH} 7.4$.

11. Store at $-20^{\circ} \mathrm{C}$.

\section{Results}

Approximately $50 \mathrm{mg}$ microsomes are obtained from $10 \mathrm{~g}$ wet weight liver.

\section{Peroxisomes of rat liver}

\section{Protocol}

1. Inject clofibrate $(200 \mathrm{mg} / \mathrm{kg})$ subcutaneously once a day consecutively for two weeks.

2. Perfuse rat liver with cold saline.

3. Cut into pieces with scissors and suspend in $4 \mathrm{~mL} / \mathrm{g}$ of wet weight sucrose $(0.25 \mathrm{M})$ containing ethanol $(0.1 \% \mathrm{v} / \mathrm{v})$. (Ethanol is added to prevent inactivation of catalase.)

4. Homogenize with a Potter-Elvehjem type homogenizer (3-5 strokes).

5. Centrifuge at $1000 \mathrm{~g}$ for $10 \mathrm{~min}$ (Hitachi RP20, $3700 \mathrm{rpm}$ ).

6. Homogenize the pellet in 2 vol. of the same buffer.

7. Centrifuge at $1000 \mathrm{~g}$ for $10 \mathrm{~min}$.

8. Combine the supernatant from procedures 5 and 7 .

9. Centrifuge the combined supernatant at $20000 \mathrm{~g}$ for $15 \mathrm{~min}$ (Hitachi RP20, $16600 \mathrm{rpm}$ ).

10. Suspend the pellet in the same buffer and homogenize.

11. Centrifuge at $20000 \mathrm{~g}$ for $15 \mathrm{~min}$.

12. Repeat procedures 10 and 11 .

13. Suspend and homogenize in a small volume of sucrose $(0.25$ M) containing ethanol $(0.1 \% \mathrm{v} / \mathrm{v})$.

14. Store at $-20^{\circ} \mathrm{C}$.

Results

50-100 mg peroxisomes are obtained from $10 \mathrm{~g}$ wet weight liver.

Measurement of the production of superoxide anion $\left(\mathrm{O}_{2}^{-}\right)$

$0_{2}{ }^{-}$-is produced by complex 1 and ubisemiquinone in mitochondria, and by cytochrome P-450 in microsomes.

\section{Mitochondria}

Epinephrine (adrenaline) is reduced to adrenochrome by $\mathrm{O}_{2}^{-}[1]$

\section{Protocol}

1. Prepare reaction mixture: Hepes- $\mathrm{NaOH}(\mathrm{pH} 7.5,100 \mathrm{mM})$ containing sucrose $(0.5 \mathrm{M}),(500 \mu \mathrm{L}$; final concentration 50 $\mathrm{mM} / 0.25 \mathrm{M})$; water $(450 \mu \mathrm{L})$; rotenone in ethanol $(100 \mu \mathrm{M}, 10$ $\mu \mathrm{L}$; (final concentration $1 \mu \mathrm{M})$; epinephrine $(200 \mathrm{mM}, 5 \mu \mathrm{L}$; final concentration $1 \mathrm{mM})$; bovine heart SMP $(20 \mathrm{mg} / \mathrm{mL}, 25$ $\mu \mathrm{L}$; final concentration $0.5 \mathrm{mg} / \mathrm{mL}$ ); total volume $990 \mu \mathrm{L}$.
2. Preincubate at $37^{\circ} \mathrm{C}$ for $5 \mathrm{~min}$.

3. Record the baseline at $485-575 \mathrm{~nm}$ (Hitachi spectrophotometer 557) for at least $1 \mathrm{~min}$.

4. Start the reaction by adding NADH $(20 \mathrm{mM}, 10 \mu \mathrm{L})$ in Hepes$\mathrm{NaOH}(\mathrm{pH} 7.5,50 \mathrm{mM})$ or in sodium succinate (pH 7.0, $2 \mathrm{M})$ (final concentrations $0.2 \mathrm{mM}$ or $20 \mathrm{mM}$, respectively).

5. Add $10 \mu \mathrm{L} 1 \mathrm{mg} / \mathrm{mL}$ superoxide dismutase (SOD) [2].

\section{Results and calculations}

The SOD inhibitable reduction of epinephrine is calculated as the reduction by $\mathrm{O}_{2}^{-}$(Figure 1 ). The absorbance coefficient for adrenochrome is $2.96 \mathrm{mM} / \mathrm{cm}$.

\section{Microsomes}

Preparation of acetylated cytochrome-c.

The reduction of cytochrome-c by endogenous electron-transfer systems in microsomes is reduced to below $10 \%$ by acetylation of cytochrome-c.

\section{Protocol}

AII procedures should be performed at temperatures below $4^{\circ} \mathrm{C}$.

1. Dilute saturated sodium acetate $(2.5 \mathrm{~mL})$ with distilled water $(2.5 \mathrm{~mL})$.

2. Add cytochrome-c(horse heart, Sigma; $50 \mathrm{mg}$ ) with stirring.

3. Add acetic anhydride $(64 \mu \mathrm{L})$ slowly.

4. Allow the reaction to continue for $60 \mathrm{~min}$.

5. Dialyse twice for $12 \mathrm{~h}$ in $2 \mathrm{~L}$ water at $4^{\circ} \mathrm{C}$.

6. Determine the concentration and store at $-20^{\circ} \mathrm{C}$.

Measure the increase in absorbance at $550-540 \mathrm{~nm}$ in Hepes$\mathrm{NaOH}(\mathrm{pH} 7.5,50 \mathrm{mM})$ after reduction by addition of a small amount of powdered $\mathrm{Na}_{2} \mathrm{~S}_{2} \mathrm{O}_{4}$. The millimolar absorption coefficient is $19.1 \mathrm{mM} /$ $\mathrm{cm}$. Acetylated cytochrome-c is stable to several freeze thaw cycles.

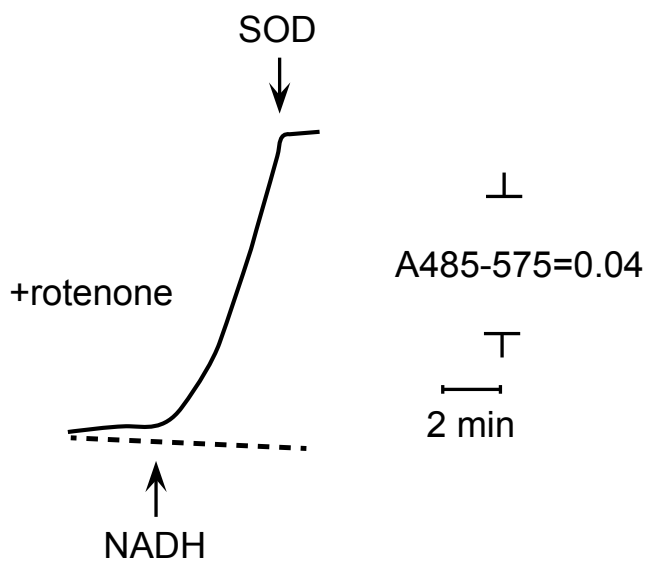

Figure 1: $\mathrm{O}_{2}^{-}$production by bovine heart SMP (submitcondrial particles) SOD: superoxide dismutase. 


\section{Measurements}

\section{Protocol}

1. Reaction mixture: Hepes- $\mathrm{NaOH}(\mathrm{pH}$ 7.7, 100 mM, 500 $\mu \mathrm{L}$; final concentration $50 \mathrm{mM})$; water $(280 \mu \mathrm{L})$; acetylated cytochrome-c $(0.3 \mathrm{mM}, 200 \mu \mathrm{L}$; final concentration $60 \mu \mathrm{M})$; rat liver microsomes $(2 \mathrm{mg} / \mathrm{mL}, 10 \mu \mathrm{L}$; final concentration $20 \mu \mathrm{g} /$ $\mathrm{mL})$; total volume $990 \mu \mathrm{L}$.

2. Preincubate at $37^{\circ} \mathrm{C}$ for $5 \mathrm{~min}$.

3. Record the baseline for ca $1 \mathrm{~min}$ at $550-540 \mathrm{~nm}$ (Hitachi spectro photometer 557).

4. Start the reaction by adding NADPH $(20 \mathrm{mM}, 10 \mu \mathrm{L})$ in Hepes$\mathrm{NaOH}$ (pH 7.7, $50 \mathrm{mM})(0.2 \mathrm{mM}$ final).

5. Add SOD $(1 \mathrm{mg} / \mathrm{mL}, 10 \mu \mathrm{L})$.

\section{Results and Calculations}

The SOD-inhibitable part is calculated as the reduction of acetylated cytochrome-c by $\mathrm{O}_{2}^{-}$(Figure 2 ).

Measurement of the production of hydrogen peroxide $\left(\mathrm{H}_{2} \mathrm{O}_{2}\right)$

$\mathrm{H}_{2} \mathrm{O}_{2}$ results from the dismutation of $\mathrm{O}_{2}$ in mitochondria and microsomes. In peroxisomes $\mathrm{H}_{2} \mathrm{O}_{2}$ is produced by acyl coenzyme $\mathrm{A}$, an oxidase which is involved in the beta-oxidation of fatty acids.

\section{Mitochondria-scopoletin method}

\section{Protocol}

1. Reaction mixture: Tris-MOPS $(\mathrm{pH} 7.4,60 \mathrm{mM})$ containing mannitol $(0.46 \mathrm{M})$ and sucrose $(0.14 \mathrm{M}), 1000 \mu \mathrm{L}$ (final concentration $30 \mathrm{mM}, 0.23 \mathrm{M}$, and $0.07 \mathrm{M})$; water $(740 \mu \mathrm{L})$; horseradish peroxidase (RZ > 3; Sigma; $100 \mu \mathrm{M}, 20 \mu \mathrm{L}$; final concentration $1 \mu \mathrm{M})$; SMP $(200 \mu \mathrm{L}$, final concentration $1 \mu \mathrm{M})$; scopoletin in ethanol $(200 \mu \mathrm{M}, 10 \mu \mathrm{L}$; final concentration 1 $\mu \mathrm{M})$; total volume $2980 \mu \mathrm{L}$.

2. Preincubate at $37^{\circ} \mathrm{C}$ for $5 \mathrm{~min}$.

3. Record baseline fluorescence ( $\lambda$ ex $365 \mathrm{~nm}, \lambda$ em $450 \mathrm{~nm})$.

4. Start the reaction by adding sodium succinate $(1 \mathrm{M} 20 \mu \mathrm{L} ; 10$ $\mathrm{mM}$ final) and record the decrease in the fluorescence.

\section{Microsomes-catalase Method}

\section{Protocol}

1. Reaction mixture: Tris-HCI ( $\mathrm{pH} 7.5,100 \mathrm{mM})$ containing KCI (0.3 M) and $\mathrm{MgCl}_{2}(20 \mathrm{mM}, 3.75 \mathrm{~mL})$; water $(2.13 \mathrm{~mL})$;

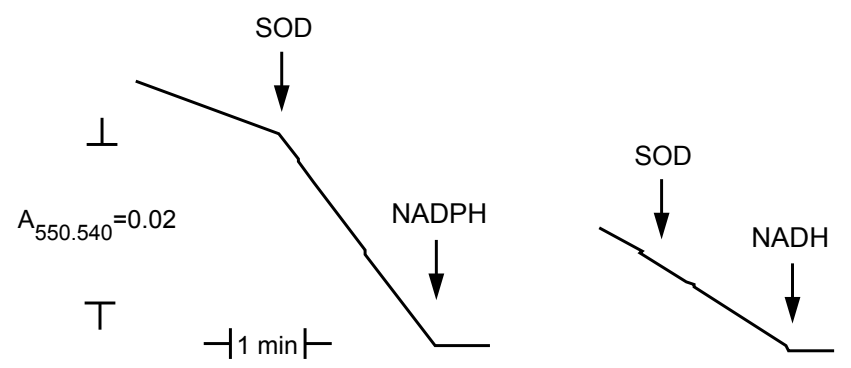

Figure 2: $\mathrm{O}_{2}^{-}$-production by rat liver microsomes SOD: superoxide dismutase. trisodium isocitrate $(80 \mathrm{mM}, 750 \mu \mathrm{L}$; final concentration 8 $\mathrm{mM}$ ); isocitrate dehydrogenase (Oriental; 100 units $/ \mathrm{mL}, 25$ $\mu \mathrm{L}$; total amount 0.3 units); catalase (Boehringer-Mannheim; $13 \times 10^{5}$ units/mL, $5 \mu \mathrm{L}$; total amount 867 units); methanol (15 $\mu \mathrm{L}$; final concentration $3 \mathrm{mM})$; rat liver microsomes $(750 \mu \mathrm{L}$, $15 \mathrm{mg} / \mathrm{mL}$; final concentration $1.5 \mathrm{mg} / \mathrm{mL}$ ); total volume 7.425 $\mathrm{mL}$.

2. Preincubate at room temperature for $5 \mathrm{~min}$.

3. Start the reaction by adding NADPH $(40 \mathrm{mM}, 75 \mu \mathrm{L} ; 0.4 \mathrm{mM}$ final).

4. Take aliquots $(500 \mu \mathrm{L})$ every $2 \mathrm{~min}$ and add to ice-cold trichloroacetic acid (TCA; 15\%, $500 \mu \mathrm{L}$ ) in an Eppendorf tube.

5. Centrifuge at $6000 \mathrm{~g}$ for $10 \mathrm{~min}$ (Tomy TMA-2, $10000 \mathrm{rpm}$ ).

6. Mix the supernatant $(750 \mu \mathrm{L})$ with Nash reagent $(750 \mu \mathrm{L})^{\prime}$.

7. Heat at $58^{\circ} \mathrm{C}$ for $10 \mathrm{~min}$.

8. Cool to room temperature.

9. Measure absorbance at $412 \mathrm{~nm}$.

\section{Peroxisomes-Catalase Method}

\section{Protocol}

1. Reaction mixture: Tris-HCI ( $\mathrm{pH} 7.5,100 \mathrm{mM})$ containing $\mathrm{KCI}$ $(0.3 \mathrm{M}, 1.0 \mathrm{~mL}$; final concentrations $50 \mathrm{mM}$ and $0.15 \mathrm{M})$; water $(896 \mu \mathrm{L})$; methanol $(4 \mu \mathrm{L}$; final concentration $3 \mathrm{mM})$; rat liver peroxisomes $(20 \mathrm{mg} / \mathrm{mL}, 50 \mu \mathrm{L}$; final concentration $0.5 \mathrm{mg} /$ $\mathrm{mL}$ ); total volume $1.95 \mathrm{~mL}$.

2. Preincubate at room temperature for $5 \mathrm{~min}$.

3. Start the reaction by adding palmitoyl-CoA $(10 \mathrm{mM}, 50 \mu \mathrm{L}$; dissolve before use, $0.2 \mathrm{mM}$ final).

4. Take aliquots $(500 \mu \mathrm{L})$ at 0,1 , and 2 min and add to ice-cold TCA $(15 \%, 500 \mu \mathrm{L})$.

5. Proceed as for microsomes.

\section{Lipid peroxidation}

Ferric salts are reduced to the ferrous state by the mitochondrial or microsomal electron transport systems, and ferrous salts are more active in redox reactions leading to lipid peroxidation. Malondialdehyde (MDA), a degradation product resulting from lipid peroxidation reactions, is a widely used quantitative marker for lipid peroxidation.

\section{Mitochondria MDA quantitation by HPLC}

\section{Preparation of standard MDA}

1. Dissolve $1,1,3,3$ - tetraethoxypropane (Sigma; $0.1 \mathrm{mM}$ ) in $\mathrm{HCl}$ (18 mM, $10 \mathrm{~m} \mathrm{~L})$.

2. Heat at $50^{\circ} \mathrm{C}$ for $1 \mathrm{~h}$

3. Dilute the sample $(20 \mu \mathrm{L})$ to $10 \mathrm{~mL}$ with water and store at $4^{\circ} \mathrm{C}$. The millimolar absorption coefficient at $267 \mathrm{~nm}$ is 31.8 $\mathrm{mM} / \mathrm{cm}$.

\section{Lipid peroxidation reaction and quantitation of MDA}

\section{Protocol}

1. Reaction mixture: Hepes- $\mathrm{NaOH}(\mathrm{pH} 7.4,100 \mathrm{mM}, 250 \mu \mathrm{L}$; final concentration $50 \mathrm{mM})$; water $(205 \mu \mathrm{L})$; bovine heart SMP $(10$ $\mathrm{mg} / \mathrm{mL}, 15 \mu \mathrm{L}$; final concentration $0.3 \mathrm{mg} / \mathrm{mL})$; ADP $(100 \mathrm{mM}$, 
$10 \mu \mathrm{L}$; final concentration $2 \mathrm{mM}$ ); $\mathrm{FeCI}_{3}$ (freshly prepared; 10 $\mathrm{mM}, 10 \mu \mathrm{L}$; final concentration

$0.2 \mathrm{mM})$; rotenone in ethanol $(100 \mu \mathrm{M}, 5 \mu \mathrm{L}$; final concentration $1 \mu \mathrm{M})$; total volume, $495 \mu \mathrm{L}$.

2. Preincubate at room temperature for $5 \mathrm{~min}$.

3. Start the reaction by adding $\mathrm{NAD}(\mathrm{P}) \mathrm{H}(10 \mathrm{mM}, 5 \mu \mathrm{L} ; 0.1 \mathrm{mM}$ final).

4. Stop the reaction by adding acetonitrile $(1 \mathrm{~mL})$.

5. Leave to stand at room temperature for more than $5 \mathrm{~min}$.

6. Centrifuge at $6000 \mathrm{~g}$ for $10 \mathrm{~min}$ (Tomy TMA-2, $10000 \mathrm{rpm}$ ).

7. Use the supernatant $(50-100 \mu \mathrm{L})$ for HPLC analysis on a 4.6 mm i.d. $\times 150 \mathrm{~mm}$ Chemcopac Spherisorb- $\mathrm{NH}_{2}$ column with 2:8 (v/v). Tris-HCI ( $\mathrm{pH} 7.4,30 \mathrm{mM})$-acetonitrile as mobile phase at $2.0 \mathrm{~mL} / \mathrm{min}$ detection wavelength $267 \mathrm{~nm}$.

\section{Result and Calculation}

The amount of MDA in the sample is calculated by comparing its peak area with that from standard MDA (Figure 3).

\section{Comments}

When succinate is used as an electron donor, rotenone is replaced by 2 -theonyltrifluoroacetone (TTFA, $1 \mathrm{mM}$ final). The buffer solution used to suspend the SMP should be replaced by Hepes- $\mathrm{NaOH}$ ( $\mathrm{pH} 7.4$, $10 \mathrm{mM}$ ) if MDA is measured by the following TBA method.

\section{Microsomes-thiobarbituric acid (TBA) method}

\section{Protocol}

1. Reaction mixture: Hepes- $\mathrm{NaOH}$ (pH 7.4, 100 mM. $250 \mu \mathrm{L}$; final concentration $50 \mathrm{mM})$; water $(220 \mu \mathrm{L})$; ADP $(100 \mathrm{mM}$, $10 \mu \mathrm{L}$; final concentration $2 \mathrm{mM}$ ); $\mathrm{FeCI}_{3}$ (freshly prepared; 10

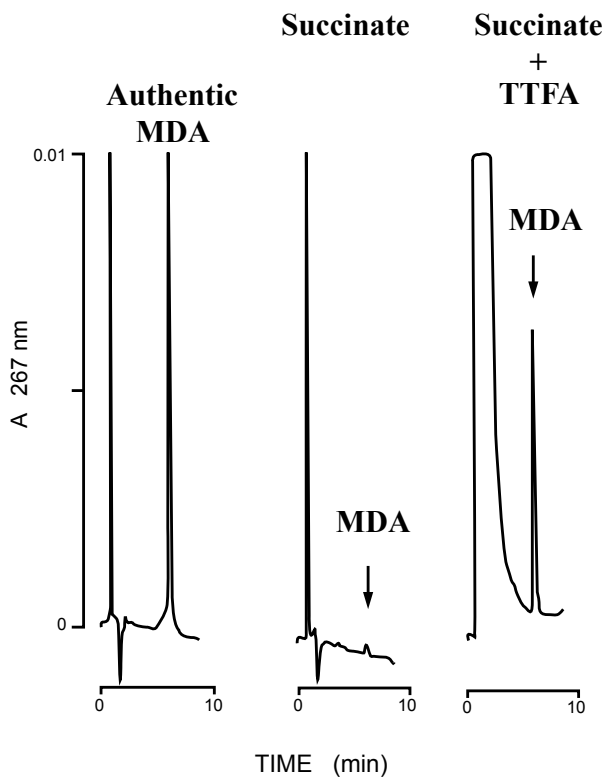

Figure 3: Lipid peroxidation in SMP (2) MDA: Malondialdehyde, TTFA:
$\mathrm{mM}, 10 \mu \mathrm{L}$; final concentration $0.2 \mathrm{mM}$ ); rat liver microsomes $(20 \mathrm{mg} / \mathrm{mL})$ in $\mathrm{KCI}(0.15 \mathrm{M}, 5 \mu \mathrm{L}$; final concentration $0.2 \mathrm{mg} /$ $\mathrm{mL})$; total volume $495 \mu \mathrm{L}$.

2. Preincubate at room temperature for $5 \mathrm{~min}$.

3. Start the reaction by adding NADPH $(20 \mathrm{mM}, 5 \mu \mathrm{L} ; 0.2 \mathrm{mM}$ final).

4. Stop the reaction by adding ice-cold TCA $(100 \%, 0.5 \mathrm{~mL})$.

5. Add butylhydroxytoluene $(10 \mathrm{mM}, 5 \mu \mathrm{L})$ in ethanol to prevent non-enzymic lipid peroxidation in subsequent steps.

6. Stand on ice for at least $10 \mathrm{~min}$.

7. Centrifuge at $6000 \mathrm{~g}$ for $10 \mathrm{~min}$ (Tomy TMA-2, $10000 \mathrm{rpm}$ ).

8. Add supernatant $(0.5 \mathrm{~mL})$ to TBA $(0.375 \%, 0.5 \mathrm{~mL})$ '.

9. Heat at $80^{\circ} \mathrm{C}$ for $15 \mathrm{~min}$.

10. Cool to room temperature.

11. Measure absorbance at $535 \mathrm{~nm}$.

\section{Comments}

The reaction of TBA is not specific for MDA. The absorbance values are, therefore, used for the quantitation of lipid peroxidation and expressed as TBA-reactive substances (TBARS).

\section{References}

1. Takeshige K, Minakami S (1979) NADH- and NADPH-dependent formation of superoxide anions by bovine heart submitochondrial particles and NADHubiquinone reductase preparation. Biochem J 180: 129-135.

2. Eto Y, Kang D, Hasegawa E, Takeshige K, Minakami S (1992) Succinatedependent lipid peroxidation and its prevention by reduced ubiquinone in beef heart submitochondrial particles. Arch Biochem Biophys 295: 101-106. 